\title{
Analysis on the characteristics of Shanghai Pilot Free Trade Zone
}

\author{
Yu Song \\ Department of International Trade Shandong University of Finance and Economics, Shandong Province, China \\ sophie.sy0@gmail.com
}

\begin{abstract}
Nowadays, there are more than 1200 free trade zones throughout the world varied from different factors such as geographic location and economic policy. The functions of the global free trade zone have developed significantly from only traditional export and re-export trade to finance, science and technology. Shanghai, as the world's largest port which began direct trade relations with Western nations starting in 1843, becomes focus of the world because of the foundation of Shanghai Pilot Free Trade Zone.
\end{abstract}

Index Terms - International Trade, Free Trade Zone

\section{Introduction}

Shanghai, as one of the most modern and international cities in China, had and continues to have an important role in China's trade. Shanghai is a good starting point for understanding China's trade dynamics. Today it has the largest port in the world, and in the mid-nineteenth century, under the pressure of British military threat, Shanghai granted access to merchants from Western countries seeking wider markets in China. However, after the World War II, growth in Shanghai stopped by restrictive economic policies. Later on, it recovered since the year of 1978 reforms.

At present, the volume of China's trade is increasing with the foreign presence in China and has a broad influence on both international and domestic economy. Under the background that global trade competition among nations is more and more sharp, China must take active measures to obtain favorable advantages in global competiton. Considering this background, China actively set up a free trade zone in which all nations around the world are permitted to trade and invest without limitation. Once the establishment Shanghai Pilot Free Trade Zone attains the anticipatory aim, its fundamental mode then can be further promoted in other Chinese regions. With the need of globalization in China, some experts proposed to adopt a more open trade regime and a broader openness. Then, at September 29th in 2013, the Shanghai Pilot Free Trade Zone was formally established.

Shanghai Pilot Free Trade Zone, which is located in Shanghai, is the first free trade zone inside mainland China and is supposed to bring profit to Shanghai in ten years. In August 2013, government officially approved Shanghai Pilot Free Trade Zone to be set up. Centered on Shanghai Waigaoqiao Free Trade Zone, Shanghai Pilot Free Trade Zone becomes the new and giant laboratory for testing China's ecomonic policies which is different from those performing now. Shanghai Pilot Free Trade Zone will implement measures to transform the functions of the government, reform the financial system, service trade, foreign investment, as well as tax policy, in the mean time, it will Vigorously promote the development of international trade in Shanghai.

It is prior to carry and try many new functions such as international trade settlement center, finance lease, expand the scale of warehouse and ship registrations, promote the integration of airport area and port to make substantive progress, promote the asia-pacific carriers plan in an all-round manner, Pilot maintenance detection business around the world, adopt global maintenance and detection business pilot, and study the creation of international account which keeps the characteristic of offshore.

The foundation of Shanghai Pilot Free Trade Zone contributes to the establishment of a huge buffer and reservior for financial asset and perfection of RMB's global circulation path, and eventually realizes global optimal allocation of financial resources thus making RMB holds an increasingly high international status.

\section{Analysis on the Characteristics of Shanghai Pilot Free Trade Zone}

Understanding the characteristics of Shanghai Pilot Free Trade Zone is key to understanding the occurrence and significance of it. Regional economic integration has 4 main stages: first, free trade zone; second, customs union; third, common market; fourth, economic union. Traditionally, free trade zone refers to place where two or more countries cancel the measures of custom duty and others which have the same effect by reaching agreements or treaties. Countries in customs union implement the free trade policy to every other member. The degree of integration of common market is deeper than that of customs union with free flowing of the factors. The highest level of integration refers to economic union, which has uniform social and economic policies such as monetary policy and fiscal policy. The United States and 22 other countries signed the General Agreement on Tariffs and Trade (GATT), "paving the way for the first effective worldwide tariff agreement"[1]. In normal conditions, the agreement covers 3 main points:(1)trade shall be conducted on a nondiscriminatory basis;(2)protection shall be afforded domestic industries through customs tariffs, not through such commercial measures as import quotas; and(3) consultation shall be the primary method used to slove global trade problems.

The establishment of Shanghai Pilot Free Trade Zone has highlighted 4 major aspects making Shanghai Pilot Free Trade Zone more advanced than conventional ones. First of all is the 
trade liberalization that goods can freely import, produce, and export without the intervention of neither the customs supervision and control nor tariffs. Instead of becoming the port with the largest container throughput, Shanghai Pilot Free Trade Zone is aiming at doing transit trade and offshore business. The core of Shanghai Pilot Free Trade Zone is between 2 segments: attracting multinational company headquarters and constructing transaction platforms. The core of offshore business is dealing with the controls over multinational companies' capital. Reacting to this situation, in Shanghai Pilot Free Trade Zone, companies are allowed to keep both international capital pool and domestic capital pool linked with interconnected pipes. Thus, order and capital link is done in Shanghai while the good in reality does not necessarily pass through ports in Shanghai. These measures will not only stimulate the development of relevant service trade and service outsourcing industry(including finance lease, inspection and maintenance, and accounting), but also reduce the multinational companies' cost and the entry threshold of global resource allocation and commodity price risk management, and eventually will contribute to the prosperity of free trade zone.

The second one is the investment liberalization that preestablishment national treatment and negetive list is fully implemented in this zone. This is particularly directing at service industry, for instance, financial service, shipping service, merchandising and trade related services, professional service, social service, and cultural service. It has been found that every sphere which opens more thoroughly and participates actively in international competition, whether in services or manufacturing, is bound to experience a better development and have a stronger competitiveness. Besides, it may also be a preview for the ongoing bilateral investment treaty's negotiation between China and the United States. For the first time national treatment for foreign investors extends to post-establishment national treatment and there will be no more administrative controls relied on present the Catalogue for the Guidance of Foreign-Invested Industries. It is also meaningful for Chinese government's instituitional reform, which is committed to negate the existing government approvals as well as the corresponding capacity to rentcreating and rent-seeking. What's more, investment is bidirectional to encourage Chinese capital's foreigh investment directly from the free trade zone. It is encouraged of the foundation of foreign equity investment funds with relevant intermediary services making Shanghai Pilot Free Trade Zone a platform for Chinese capital to participate in international affairs and advance the strategy of "going global". "Operating returns increase significantly from the year before to the year after buyouts as measured by operating cash flows (before interest and taxes) per employee and per dollar of operating assets."'[2]

The third one is the internationalization of finance to expand currency's global reach while loosening the controlling of capital account is indispensable to realize it. At the same time, innovating in supervisor mode about the corporation's foreign debt is seeking to realize centralized management on foreign exchange funds in order to build a global capital management center for multinational coporations. In the future, development of free trade in terms of finance is bond to have a significant impact. The first step is to initially realize functions of free trading and offshore finance like Hong Kong and Singapore allowing Chinese-funded banks in Shanghai Pilot Free Trade Zone to engage in offshore business. Then, allow funds within the certain range or limit interpenetrated with others. Finally, on the premise of risk control and efficiency improvement, form a similar form as London's, a truly comprehensive infiltration and integration of global financial centre.

The fourth one is the simplification of administration which leads to decrease in administrative cost .It is predictable that administrative functions will be gathered into one government organization in the near future thus achieving final purpose to establish a centralized and unified market regulatory system, transform the function of the government, improve the administrative transparency, carry out local legislation experiment and perfom functions of protecting the rights and interests of investors.

The most spectacular aspect of the pilot project is financial application which includes not only the interest rates liberalization, free exchange of exchange rates, opening up of financial industry, product innovation, but aloso the offshore business, while this pilot project also indicates the openness of RMB capital account.

Offshore financial business is an important part of Shanghai Pilot Free Trade Zone's constitutions echoed by the openness of RMB capital account with the currency exchange rate issuing regime's objective to accelerat $r$ outflows' turnover thus improve the efficiency of the RMB's use.

As for tax preference, it is referred to overall solution as enterprises or individual shareholders who are registered in the pilot zone can be offered with tax preference on the valueadded part of asset evaluation which is resulted from asses's behavior of rearrangement such as non-currency assets of foreign investment in no more than five years. It is obvious that Shanghai Pilot Free Trade Zone's tax preference policy's level is lower than expected.

In addition, the innovations of regulatory model in the field of trade which aims at the efficiency of people and goods' flow and of foreign trade and logistics is also listed.

The United States is one among the other countries absorbing most foreign direct investments. Although it establishes and strengthenes national security censorship against foreign capital, the United States also adoptes a series of tax break policy to attract foreign investment. Goods are free of custom declaration and custom pay if they enter free trade zone legally. In New York Free Trade Zone, it is allowed to delay import duty's pay, freely choose whether to pay the custom of ingredient or finished product by setting up a factory, export without duty, and simplify the process of import and export. Compared with United States, Shanghai 
Pilot Free Trade Zone also decreases import tariff and speeds up the efficiency of import and export custom check.

Cayman Island, which is the fourth largest offshore financial center in the world, has only a few plain tax policies like import tax, industrial and commercial registration tax, but no personal income tax, corporate income tax, capital gains tax, or real estate tax. Other famous global offshore financial centers like British Virgin Islands and Hong Kong have only a little limit to offshore enterprises which don't do real business in their registered region without any tax and only a small amount of management fees. Offshore financial center has three main characteristics as high degree of confidentiality, tax relief and no control of foreign exchange. However, on the one hand, in Shanghai Pilot Free Trade Zone, almost all tax policies are still using, only enterprises or individual shareholders who are registered in the pilot zone can be offered with tax preference on the value-added part of asset evaluation which is resulted from asses's behavior of rearrangement such as non-currency assets of foreign investment in no more than five years, which means that corporations are likely to save only a little cost on taxes like income taxes. On the other hand, as can be known from the list of entered enterprises, rigid review mechanism on enterprises' entering requirements still exists in Shanghai Pilot Free Trade Zone, while in other countries and regions such as Cayman Island, conditions of company's establishment are quite succinct with high level of protection about private profiles, which makes those countries and regions become a lot of companies' preferred register areas

In countries and regions like Cayman Island and Singapore, investment field is more open than that is in mainland China. Since the need of openness in investment in China is becoming impending, Shanghai Pilot Free Trade Zone has expanded the openness of service trade in, for example, financial service and cultural service by suspending or canceling access restrictions on investor's qualification requirements, share ratio, and business scope to construct a market environment with equal access to all kinds of investors. In financial instituitions, the implementation of market-based pricing model aims to realize the facilitation of trade investment and encourages corporations to make the full use of two markets as international market and domestic market in order to achieve coss-border financing liberalization.
In terms of legal action, law environment in regions such as Cayman Islands is extraordinarily lenient. Because of the special position United States occupies in global economic system, many conventions in the current international business practices are the product of Anglo-American law system as a matter of fact, what is more, since places such as the Cayman Islands and Bermuda are part-autonomous of the British colony, their company laws is on the basis of British commercial company law making the places more appealing for oversea companies to register at there. Meanwhile, in Shanghai Pilot Free Trade Zone, government temporarily adopts the Law of the People's Republic of China on Foreigncapital Enterprises, Law of the People's Republic of China on Chinese-foreign Equity Joint Ventures and Law of the People's Republic of China on Chinese-Foreign Contractual Joint Ventures.

\section{Concluding Remarks}

In this paper there are detailed analyses on newly established Shanghai Pilot Free Trade Zone in terms of content of policy, adopted laws, aims and so on. Compared with traditional free trade zones and modern international trade centers, Shanghai Pilot Free Trade Zone is proven to have the role of guiding policy reforms in China in purpose of increasing the level of marketing openness in international trade and finance. Considering the sustainable development of Shanghai Pilot Free Trade Zone, the government should not only adjust relevant policies to actual conditions without delay but also give companies enough operation and investment autonomy. Being a completely comprehensive pilot zone, Shanghai Pilot Free Trade Zone will undoubtedly create a marketing economic environment which is free, open, and consistent with international practice. Since Shanghai Pilot Free Trade Zone is an emerging free trade zone, more comprehensive and detailed studies about it are still needed. Besides, further research can be taken in the form of questionnaire, interview and financial sheet analysis.

\section{References}

[1] Philip R. Cateora, Mary C.Gilly, John L. Graham, International Marketing, $16^{\text {th }}$ edition, pp. 24-24, June 2013.

[2] A. J. Smith: "Corporate ownership structure and performance : The case of management buyouts",Journal of Financial Economics, September 1990 